\title{
The First Collected "Shakespeare Apocrypha"
}

\author{
Peter Kirwan
}

$\mathrm{T}$ HE DiSPARATE GROUP OF EARLY MODERN PLAYS still referred to by many critics as the "Shakespeare Apocrypha" take their dubious attributions to Shakespeare from a variety of sources. Many of these attributions are external, such as the explicit references on the title pages of The London Prodigal (1605), A Yorkshire Tragedy (1608), 1 Sir John Oldcastle (1619), The Troublesome Raigne of King John (1622), The Birth of Merlin (1662), and (more ambiguously) the initials on the title pages of Locrine (1595), Thomas Lord Cromwell (1602), and The Puritan (1607). Others, including Edward III, Arden of Faversham, Sir Thomas More, and many more, have been attributed much later on the basis of internal evidence.

The first collection of disputed plays under Shakespeare's name is usually understood to be the second impression of the Third Folio in 1664, which "added seven Playes, never before Printed in Folio." ${ }^{1}$ Yet there is some evidence of an interest in dubitanda before the Restoration. The case of the Pavier quartos, which included Oldcastle and Yorkshire Tragedy among authentic plays and variant quartos in 1619, has been amply discussed elsewhere as an early attempt to create a canon of texts that readers would have understood as "Shakespeare's," despite later critical division of these plays into categories of "authentic" and "spurious," which was then supplanted by the canon presented in the 1623 Folio. $^{2}$ I would like to attend, however, to a much more rarely examined early collection of plays-Mucedorus, Fair Em, and The Merry Devil of Edmonton, all included in C. F. Tucker Brooke's seminal The Shakespeare Apocrypha of 1908. ${ }^{3}$ They

I am grateful to Jonathan Bate, John Jowett, and Eric Rasmussen, who generously offered invaluable advice and feedback on an earlier draft of this essay.

${ }^{1}$ Mr. William Shakespear's Comedies, Histories, and Tragedies. Published according to the true Original Copies. The Third Impression. And unto this impression is added seven Playes, never before Printed in Folio ... (London: P.C., 1664).

${ }^{2}$ For excellent recent discussions, see Andrew Murphy, Shakespeare in Print (Cambridge: Cambridge UP, 2002), 36-41; Sonia Massai, Shakespeare and the Rise of the Editor (Cambridge: Cambridge UP, 2007), 106-35; and John Jowett, Shakespeare and Text (Oxford: Oxford UP, 2007), 69-72.

${ }^{3}$ C. F. Tucker Brooke, ed., The Shakespeare Apocrypha: Being a Collection of Fourteen Plays Which Have Been Ascribed to Shakespeare (Oxford: Clarendon Press, 1908). 
derive their original attribution from their inclusion in an early binding of plays inscribed with the title "Shakespeare, Vol. 1.," which originally belonged to the Royal Library. The attribution of Mucedorus and Merry Devil to Shakespeare is supported by the book catalogues of Edward Archer (1656) and Francis Kirkman (1661). Quartos of both of these plays additionally confirm that they were owned by the King's Men. The attribution of Fair Em, however, rests solely on its inclusion in "Shakespeare, Vol. 1." It is this volume that concerns this essay.

\section{Re-Dating the Volume}

Despite the volume's obvious importance to the history of these plays and its ubiquitous appearance in the footnotes of papers on Mucedorus, Fair Em, and Merry Devil, critics have been content to repeat information about the volume without cross-checking its provenance and constitution. This has led to two important features of the volume being overlooked. The volume passed into the collection of David Garrick, and it is his testimony, supported by that of Edward Capell, who catalogued Garrick's collection, that affirms the book's original provenance. The volume in turn passed into the British Museum and was broken up in the 1840s on the orders of Anthony Panizzi, along with the remainder of the Garrick bound volumes. ${ }^{4}$ Regrettably, the volume binding is no longer extant.

All twentieth-century references to the volume state that it belonged to the library of Charles II, a belief sustained in recent essays by John Jowett, Richard Preiss, and Pavel Drábek. ${ }^{5}$ However, the earliest references to the volume all concur in affirming that it in fact belonged to the library of Charles the First. Capell, who rebound it for the Garrick collection as Garr.I.VIII, unequivocally refers to Charles I in his mention of the volume in Mr William Shakespeare his Comedies, Histories, and Tragedies (1768). ${ }^{6} \mathrm{He}$ is followed by George Steevens in his 1778 The Plays of William Shakspeare, who reports that Merry Devil was "Bound up in a volume of plays attributed to Shakspeare, and once belonging to King Charles I, but now in Mr. Garrick's collection" and that Mucedorus was

\footnotetext{
${ }^{4}$ George M. Kahrl and Dorothy Anderson, The Garrick Collection of Old English Plays (London: British Library, 1982), 23.

${ }^{5}$ John Jowett, "Shakespeare Supplemented," 39-73, and Richard Preiss, "A Play Finally Anonymous," 117-39, both in The Shakespeare Apocrypha, ed. Douglas A. Brooks (Lampeter, UK: Edwin Mellen, 2007). See also Pavel Drábek, "Shakespeare's Influence on Mucedorus," in Shakespeare and His Collaborators over the Centuries, ed. Pavel Drábek, Klára Kolinská, and Matthew Nicholls (Newcastle upon Tyne, UK: Cambridge Scholars, 2008), 45-54.

${ }^{6}$ Edward Capell, ed., Mr William Shakespeare his Comedies, Histories, and Tragedies. . . ., 10 vols. (London: J. and R. Tonson, 1768), vol. 1, "Table of his Editions," sigs. f6v-f8r, esp. sig. f8r, note.
} 
"Bound up in a volume of plays attributed to Shakspeare, and once belonging to King Charles the First. See Mr. Garrick's Collection." ${ }^{7}$ These footnotes are then quoted by Edmond Malone in his 1790 Plays and Poems of William Shakspeare, in Ten Volumes. ${ }^{8}$

The error appears for the first time in the 1793 "First Variorum," in three footnotes by George Steevens that refer to the volume. ${ }^{9}$ All three citations mention "a volume" belonging to Garrick, which the notes attribute to the library of "King Charles II," “King Charles the Second," and "King Charles II," respectively, There is no reason stated for the change in purported ownership, and the fact that the footnotes are otherwise repeated verbatim from Steevens's 1778 edition suggests there has been no fresh examination of the material. The third footnote, which is repeated in the 1821 Malone-Boswell variorum edition, reads:

In Mr. Garrick's collection is a volume, formerly belonging to King Charles II, which is lettered on the back "Shakespeare, Vol. I". This volume consists of Fair Em, The Merry Devil \&C., Mucedorus, \&c. There is no other authority for ascribing Fair Em to our author. ${ }^{10}$

Where Malone followed Steevens's authority in 1790, the Malone-Boswell volume consistently follows Steevens's most recent footnotes and provides no independent evidence. Responsibility for the change thus rests solely with Steevens, whose original reference to the volume was based entirely on Capell's report, suggesting that the change is a simple mistake. George M. Kahrl, the most recent bibliographer of the Garrick collection, came to the same conclusion and silently emended the 1821 footnote to read "Charles I."11

However, the prominence of the 1821 variorum helped to preserve the mistake in critical discourse for future generations, particularly influencing scholars at the turn of the century. It was Simpson's source in School of Shakespeare (1878), on which he based his assertion that the attribution was a "tradition current in the time of Charles II." ${ }^{12}$ Both E. K. Chambers (The Elizabethan Stage

${ }^{7}$ George Steevens, ed., The Plays of William Shakespeare. In Ten Volumes. With the Corrections and Illustrations of Various Commentators; To Which Are Added Notes by Samuel Johnson and George Steevens, 2nd ed., 10 vols. (London: C. Bathurst et al., 1778), 1:260n.

${ }^{8}$ Edmond Malone, ed., The Plays and Poems of William Shakspeare, in Ten Volumes; Collated Verbatim with the Most Authentick Copies, and Revised...., 10 vols. (London: H. Baldwin, 1790), $1: 257 \mathrm{n}, 259 \mathrm{n}$.

${ }^{9}$ George Steevens, ed., The Plays of William Shakespeare. In Fifteen Volumes. With the Corrections and Illustrations of Various Commentators (London: T. Longman et al., 1793), 1:432n, $433 n, 453 n$.

${ }^{10}$ Edmond Malone and James Boswell, eds., The Plays and Poems of William Shakspeare...., 21 vols. (London: F. C. and J. Rivington et al., 1821), 2:682n.

${ }^{11}$ Kahrl and Anderson, Garrick Collection, 139.

${ }^{12}$ R. Simpson, The School of Shakespeare, 2 vols. (London: Chatto and Windus, 1878), 2:339. 
[1923] and Facts and Problems [1930]) and Sir Sidney Lee (A Life of William Shakespeare [1916]) take their references to the volume from the 1821 edition, ${ }^{13}$ and it appears to have been used as well by Brooke, who refers to "Charles the Second" throughout The Shakespeare Apocrypha, and who had certainly read Simpson. With these books as standard reference sources for all scholars subsequently working on the apocryphal plays, the error was passed on without cross-checking. A useful corollary is found in Richard Preiss's essay, which uses Arvin Jupin's edition of Mucedorus as its basis. ${ }^{14}$ Preiss compounds the error by retitling the Garrick volume "Shakespeare, Vol. II."15 This is an immediately relevant example of how easily such mistakes are made and sustained.

Unfortunately, attribution of the volume to the library of either Charles I or Charles II cannot be substantiated by independent evidence: the extant quartos are unannotated except for Capell's catalogue numbers. We do not know when the volume left the Royal Library, but it was not part of the (Old) Royal Library presented as a gift to the British Museum in 1757. However, the welldocumented history of Charles I's annotated copy of the Second Folio may provide some guidance. Sir Thomas Herbert, Charles's jailor from 1647, claimed to have been given several books - including the Second Folio-as a gift from the king. T. A. Birrell reports that the volume "belonged to Herbert, and then via Dr Richard Mead and Antony Askew, to George Steevens," before being bought back by George III. ${ }^{16}$ As Birrell points out, the dispersal of royal property in the aftermath of the war and the treatment of Charles's possessions as "relic[s] of a martyr" make it difficult to separate forged claims from genuinely dispersed volumes. However, that an authentic volume from Charles I's library made its way to Steevens affirms the possibility of his contemporary, Garrick, receiving another "Shakespeare" volume by a similar route. Charles II, by contrast, was more interested in retaining and recovering the books belonging to his father. ${ }^{17}$ In the absence of confirmatory evidence, our only authoritative source is Capell, and his ascription to the library of Charles I must cautiously stand.

${ }^{13}$ E. K. Chambers, The Elizabethan Stage, 4 vols. (Oxford: Clarendon Press, 1923), 4:12, 30, 36; E. K. Chambers, William Shakespeare: Facts and Problems, 2 vols. (Oxford: Clarendon Press, 1930), 1:538; and Sidney Lee, A Life of William Shakespeare (London: John Murray, 1916), 264.

${ }^{14}$ Arvin J. Jupin, ed., A Contextual Study and Modern-Spelling Edition of "Mucedorus" (New York: Garland Publishing, 1987), 22.

${ }^{15}$ Preiss, "A Play Finally Anonymous," in ed. Shakespeare Apocrypha, Brooks, 121.

16 T. A. Birrell, English Monarchs and Their Books: From Henry VII to Charles II (London: British Library, 1986), 45.

17 Birrell, 47. 


\section{The Constitution of the Volume}

A more significant error occasioned by critical oversight concerns the constitution of Garr.I.VIII. All references to the volume from Capell onward mention only three plays-Mucedorus, Fair Em, and Merry Devil-with the increasing implication that this is exhaustive, as in Simpson's note that "the volume contained also [in addition to Mucedorus] Fair Em, and another"18 and Roslyn Knutson's suggestion that, as the two other plays in the volume belonged to Shakespeare's company, so Fair Em may have come from the same company. ${ }^{19}$ However, as George Kahrl and Dorothy Anderson observe in their catalogue of the Garrick collection, the volume actually contained no fewer than eight plays, bound in the following order (with publication dates in parentheses):

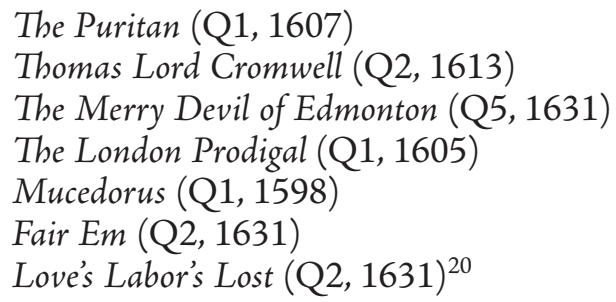

The eighth play was a copy of 1 Sir John Oldcastle (1600), as noted on Capell's flyleaf for Garr. I.VIII, but was apparently sold as a duplicate following the dispersal of the volume's contents in the British Museum. ${ }^{21}$ Capell's footnote to the volume reads, "It is worth remarking, that this volume, bound as it is, belong'd to K. Charles the first, and is titl'd upon the back, Shakespeare. Vol. I,"22 Kahrl confirms that Capell appears to have left this volume in its original binding, or at least did not break up and disperse the contents. He listed the eight items, which included one Shakespeare play and others ascribed to him, consecutively; the Capell flyleaf is of a different paper than that used for the other flyleaves, indicating that the volume was not rebound. ${ }^{23}$

${ }^{18}$ R. Simpson, "On Some Plays Attributed to Shakespeare," New Shakspere Society's Transactions ser. 1, vols. 3-4 (1875-76): 155-80, esp. 157.

${ }^{19}$ Roslyn Evander Knutson, The Repertory of Shakespeare's Company, 1594-1616 (Fayetteville: U of Arkansas P, 1991), 184.

${ }^{20}$ As listed on Capell's flyleaf for the volume, preserved in the British Library. See Edward Capell, A Catalogue of Plays; The Collection of David Garrick Esq., 2 vols., British Library 643.I.30.

${ }^{21} \mathrm{Kahrl}$ and Anderson, Garrick Collection, 128.

22 Capell, Catalogue of Plays; quoted in Kahrl and Anderson, 199.

${ }^{23}$ Kahrl and Anderson, 199. 
Kahrl thus supports Capell's claim that, while most of the plays from the Garrick collection originated from the Harleian library via Robert Dodsley, ${ }^{24}$ this volume from a different source had already been bound separately, and that the plays already bound together continued to be grouped until divided by Panizzi in the nineteenth century.

How, then, have 350 years of scholarship on the apocryphal plays failed to notice that the volume contained five other plays? I would argue that this is due in no small part to Capell's tortuous referencing mechanism in the original notes in his table of plays ascribed to Shakespeare.

And the seven, with single asterisks, are publish'd with his other plays in a folio edition printed in 1664, and in some editions since. O.C. signified, old catalogues; in some of which, these two plays are scrib'd to Shakespeare: and the remaining three, distinguish'd by crosses, are in a volume, now in $\mathrm{Mr}$. Garrick's possession, that did belong to king Charles the first, which is titl'd upon the back, "SHAKESPEAR Vol. 1:" and these likewise are given to him by old catalogues, "Fair Em" excepted, which is therefore differenc'd by having but one cross-bar. ${ }^{25}$

Capell's system of categorization is based on a hierarchy of strength of attribution to Shakespeare. Love's Labor's Lost is treated as authentic and is not discussed by him in this section. The London Prodigal, The Puritan, Sir John Oldcastle, and Thomas Lord Cromwell were included in the second impression of the 1664 Shakespeare Third Folio and are thus marked with single asterisks. Mucedorus, Fair Em, and Merry Devil are the only plays remaining whose attribution to Shakespeare needs to be supported by inclusion in the Charles I volume; the crosses distinguish them from the other two plays whose evidence for attribution is based solely on old catalogues: Edward III (1595) and The Arraignment of Paris (1584). The plays are "in a volume" (emphasis added); they do not constitute the entire volume, as has subsequently been assumed.

As a result, our understanding of the nature of these early attributions is altered significantly. The size of this volume and the inclusion of four non-Folio plays with an explicit or implied Shakespearean attribution show that the binder of the collection was attempting to compile a collection of Shakespeareana. It is, in fact, the first attempt to create a "Shakespeare apocrypha" in the sense that, with the odd exception of Love's Labor's Lost, it compiles noncanonical plays under a single heading. Further, the volume responds immediately to the book-

${ }^{24}$ A useful summary is provided by Moelwyn I. Williams, ed., A Directory of Rare Books and Special Collections in the United Kingdom and the Republic of Ireland (London: Library Association, 1985), 110-11.

${ }^{25}$ Capell, ed., Mr William Shakespeare his Comedies, vol. 1, sig. f8r, note. 
selling market of the day. Three of the quartos are dated 1631, which becomes the earliest possible date for the compilation. This goes some way to supporting the ascription to Charles I's library, and suggests that the reason for the inclusion of the canonical Love's Labor's Lost and the previously unassigned Merry Devil and Fair Em was their recent republication, making them available to pad out the compilation.

\section{IMPLICATIONS}

The correct date and constitution for the volume have some further interesting implications. One weakens the volume's support for Knutson's proposed attribution of Fair Em to the Chamberlain's-King's Men's ownership. Where its presence in a three-play volume with two other company plays seemed promising, its inclusion instead in an eight-play volume incorporating plays belonging to the Children of Paul's (The Puritan) and the Admiral's Men (Oldcastle) reminds us that the plays do not have a homogenous origin and that the volume provides no evidence for company attribution.

Second, and much more significantly, the collection provides evidence of a much earlier association of several of these plays with Shakespeare than was previously thought. Of the eight, only three (Oldcastle, London Prodigal, Love's Labor's Lost) had been explicitly attributed to Shakespeare by 1623 . Two more (Cromwell, The Puritan) were attributed to "W.S." The Third Folio is usually considered to be the first authority unambiguously to print these plays as Shakespeare's in 1664, when they and the similarly initialed Locrine were added to the canon. The earliest alternative ascriptions of Mucedorus and Merry Devil, meanwhile, are the booksellers' catalogues of 1656 and 1661.

The re-dating of the Charles I volume to the years immediately following 1631 allows us to backdate the association of Shakespeare's name with Cromwell, Puritan, Mucedorus, Fair Em, and Merry Devil by some thirty years. This is vital to our understanding of the formation of the Shakespeare canon and apocrypha. The spate of attributions in the 1650s and 1660s can be explained by the rupture in professional playing and the distance from the plays' original circumstances of production, but the Charles I volume shows that the notion of a Shakespearean "supplement" or "apocrypha" already existed in the Caroline period, taking shape as early as a decade after the publication of the First Folio and implying that the "canon" established by that volume was already unstable in discourse.

While the Charles I volume was a unique nonce collection and would therefore have only a limited readership and impact, the importance of such collections should not be underestimated. Sonia Massai's recent groundbreaking work on early modern readers of Shakespeare makes a compelling case for the importance of nonce collections and annotating readers both in shaping Shake- 
speare's works and in providing an insight into how Shakespeare was read and interpreted by successive generations. It suggests that the Pavier collection was deliberately designed to resemble a nonce collection in order to whet appetites for the Folio. ${ }^{26}$ In a manner not dissimilar to the Pavier project, the Charles I volume acts as an authority, not on what Shakespeare wrote, but what could legitimately be read as Shakespearean; as a one-off compilation for an individual library rather than a publishing project, the volume's attribution to Shakespeare has readerly rather than commercial implications.

Eric Rasmussen and Richard Proudfoot have recently suggested that the proliferation of quartos of disputed plays in the mid-1630s may have been a response to the publication of the Second Folio in 1632:

The considerable number of extant copies [of The Two Noble Kinsmen] suggests a sizeable print run. Perhaps the 1634 quarto was intended as a supplementary volume to be sold in association with the Shakespeare Second Folio, which was published by Cotes in 1632 and apparently reissued by Cotes and his brother, Richard, throughout the decade. The sixth quarto of Pericles, printed by Cotes in 1635, may also have been published to supplement F2. (Analogously, Humphrey Moseley published The Wilde-Goose Chase in folio in 1652 as a companion to his 1647 Beaumont and Fletcher Folio with which it is sometimes bound.) $)^{27}$

Rasmussen and Proudfoot imagine a vogue for Shakespeare in the years following the publication of the Second Folio that prompted the gathering and republication of non-Folio plays that could be presented and read as Shakespeare's. The compilation of the Charles I volume at this time may be seen as a further symptom of this trend: an early attempt to gather together plays with a potentially Shakespearean attribution, similar in kind to that carried out by Chetwind in the early 1660 s.

We should not infer from this that the Charles I volume has any unique authority on questions of attribution, or that its inclusions should have a bearing on the ongoing association of Shakespeare's name with these plays. However, through correcting some long-held bibliographic assumptions, we can see an earlier state of instability in the creation of the Shakespeare canon, with an "apocrypha" emerging almost as soon as a "canon" was consolidated in 1623. While we may never be fully able to comprehend the entirety of what early modern readers and audiences perceived to be "Shakespeare's," the Charles I volume demonstrates that even before the closure of the theaters, there were already several answers to that question.

${ }^{26}$ Massai, 115-19.

${ }^{27}$ Eric Rasmussen and G. R. Proudfoot, eds., The Two Noble Kinsmen, Malone Society Reprints (Oxford: Oxford UP, 2005), vii. 